\title{
Petitioning and the Empowerment Theory of Practice
}

\author{
Anita Hodgkiss
}

Modern legal theorists concerned with freedom of speech and assembly have virtually forgotten the First Amendment petition clause. ${ }^{1}$ The political role of petitioning has changed since colonial times, when it was a central element of direct democracy, ${ }^{2}$ but the values of human selfdetermination, expression of individual conscience and freedom of association that it embodies are still relevant. Given that expressing dissent and seeking redress of grievances are key activities for those attempting to build a movement for social change, the radical perspective on the right to petition is of particular importance. ${ }^{3}$

The first task for a radical theorist is to critique current petition clause doctrine. ${ }^{4}$ However, radical legal theory does not stop there; two types of

1. The petition clause of the First Amendment states: "Congress shall make no law . . . abridging . . the right of the people peaceably to assemble, and to petition the Government for a redress of grievances." U.S. Const: amend. I. The major works in traditional free speech theory make no more than passing mention of the right to petition, if that. See, e.g., Z. Chafee, Free SpEech in the Untred States (1941); T. Emerson, Toward a General Theory of the First AMENDMENT (1963); M. REnish, Frekdom of Expression: A Critical ANal.ysis (1984); Blasi, The Checking Value in First Amendment Theory, 1977 AM. B. Found. REs. J. 521; Meiklejohn, The First Amendment is an Absolute, 1961 Sup. Cr. Rkv. 245; Freedom of Expression: Theoretical Perspectives, 78 Nw. U.L. REv. 937 (1983). Even works on the closely related right of association do not discuss petitioning. See, e.g., Free: Speech and Association: The Supreme Colirt and the First AMEndmenr' (P. Kurland ed. 1975). Gritical Legal Studies (CLS) analyses of free speech likewise omit consideration of the petition clause. See Baker, Scope of the First Amendment Freedom of Speech, 25 UCLA L. REv. 964 (1978); Blum, The Divisible First Amendment: A Critical Functionalist Approach to Freedom of Speech and Electoral Campaign Spending, 58 N.Y.U. L. REV. 1273 (1983); Kairys, Freedom of Speech, in The Politics of Law: A Progressive Critique 140 (D. Kairys ed. 1982) [hereinafter The Polrtics of LAw].

2. See R. Bail.fy, Popul.ar Influence Upon Public Policy: Petitioning in Eighteenth Century Virginia (1979); Note, A Short History of the Right to Petition Government for Redress of Grievances, 96 YAl.E. L.J. 142 (1986).

3. See Bachmann, Lawyers, Law, and Social Change, 13 N.Y.U. Rev. L. \& Soc. Change 1, 22 (1984-1985) (progressive lawyers should focus on First Amendment law including right to petition because to facilitate mobilization théy must have access to public).

4. For a philosophical introduction to the critical method, see R. Geuss, The Idea of a CRITICal. Theory: Habermas and the Frankfurt School. (1981). The general critical enterprise as applied to legal doctrine is explained and defended in Kelman, Trashing, 36 STAN. L. REv. 293 (1984); see also Freeman, Truth and Mystification in Legal Scholarship, 90 YaLE L.J. 1229 (1981) (critical work is creative when it enables people to imagine that social institutions and legal doctrines need not be as they are). But see Macaulay, Law and the Behavioral Sciences: Is There Any There There?, 6 LAw \& Pol.'y 149, 173 (1984) (articles in law reviews will not result in positive change; traditional ways of thinking persist in face of analyses showing them false, incoherent, contradictory, and against interests of those who follow them); Watts, The Socialist as Ostrich: The Unwillingness of the Left to Confront Modernity, 50 Soc. RES. 3 (1983) (critical theory will exert no influence on 
positive approaches have been taken. One identifies the legal doctrine and practice that should prevail in an ideal democratic socialist society. ${ }^{5}$ The other suggests legal theories and practices that can bring about change. ${ }^{6}$ This Note develops a positive radical perspective of the second type, emphasizing the relevance of the idea of petitioning to the daily practice of law. I argue that the radical lawyer's ${ }^{z}$ task is to encourage individual and collective empowerment. The concept of petitioning, though problematic, provides a useful model to illustrate techniques of empowerment. Viewing the role of a lawyer as facilitating petitioning highlights the political nature of the lawyer's activities and suggests that lessons can be learned from past instances of petitioning.

To demonstrate the connection between petitioning and the radical lawyer's work, I first briefly discuss the definition and history of petitioning activity and contrast the liberal and radical approaches to the right to petition. I then review why the radical lawyer's role in building social movements has been problematic, and outline empowerment theory as a solution. With this foundation, I go on to explore the possibilities of petitioning as a method of empowerment.

American politics because of the theory's aloof, arrogant, and pessimistic tendencies). The justification of critical work does not imply that positive alternatives cannot be discussed, although critics of the CLS movement argue that CLS work does not present a coherent positive political program. See, e.g., Johnson, Do You Sincerely Want To Be Radical?, 36 STAN. L. REv. 247, 259-69, 281-89 (1984) (CLS scholars refuse to address practical issues and have no positive political programs); Schwartz, With Gun and Camera Through Darkest CLS-Land, 36 Stan. L. REv. 413, 448-52 (1984) (CLS writings offer grotesque and irresponsible proposals, not viable alternatives).

5. A viable alternative vision of law and society has been explored in works such as Frug, The City as a Legal Concept, 93 Harv. L. Rev. 1057 (1980); Unger, The Critical Legal Studies Movement, 96 HARv. L. REv. 561 (1983). For a sympathetic criticism of CLS positive programs, see Hutchinson \& Monahan, Law, Politics, and the Critical Legal Scholars: The Unfolding Drama of American Legal Thought, 36 STAN. L. Rev. 199, 227-244 (1984).

6. A number of articles link critical legal theory to present transformative social practices. See, e.g., Abel, A Socialist Approach to Risk, 41 MD. L. Rev. 695 (1982) (decentralized socialism and risk allocation); Sparer, Gordian Knots: The Situation of Health Care Advocacy for the Poor Today, 15 Clearinghouse Rev. 1, 22-23 \& n.92 (1981) (discussing ways of reforming focus of health care advocacy). For a defense of the need for radical legal theory that assists the building of social movements, see Klare, Law-Making as Praxis, Telos, Summer 1979, at 123; Sparer, Fundamental Human Rights, Legal Entitlements, and the Social Struggle: A Friendly Critique of the Critical Legal Studies Movement, 36 STAN. L. REv. 509, 552-74 (1984). Recent articles about the implications of radical theory for the daily practice of law include Bachmann, supra note 3; Gabel \& Harris, Building Power and Breaking Images: Critical Legal Theory and the Practice of Law, 11 N.Y.U. Rev. L. \& Soc. Change 369 (1982-1983); Simon, Visions of Practice in Legal Thought, 36 Stan. L. Rev. 469 (1984). For an outline of a new descriptive paradigm for the work of solicitors in England, based on sociological research, which attempts to escape the liberal paradigm and construct new concepts as well as respond to the Classical Marxist critique of law, see Cain, The General Practice Lawyer and the Client: Towards a Radical Conception, in The Sociology of the Professions 106 (R. Dingwall \& P. Lewis eds. 1983).

7. The term "radical lawyer," as used here, identifies lawyers who share a set of political commitments loosely defined as democratic socialism. They may or may not belong to a leftist group such as the National Lawyers Guild or the Conference on Critical Legal Studies. For a brief social and intellectual history of radical lawyers as a group, see Gordon, New Developments in Legal Theory, in The Polirics of LAw, supra note 1, at 281, 281-86. 


\section{Background of the Right To Petition}

\section{A. History and Definition of Petitioning}

The evolution of petitioning as a means of political participation was important to the development of democracy in England between the thirteenth and seventeenth centuries. ${ }^{8}$ By the time of the American Revolution, the idea that people have the right to seek and expect redress of grievances from their government was widely accepted in England and America. ${ }^{\circ}$ A series of Supreme Court opinions, beginning with Crandall v. Nevada ${ }^{10}$ in 1867 , lists the right to petition as one of the privileges and immunities of national citizenship, guaranteed under article 4, section 2 of the Constitution and later under section 1 of the Fourteenth Amendment. ${ }^{11}$ These early decisions suggest that, in theory, the right to petition would have been recognized even without the petition clause of the First Amendment and are further evidence that this right was thought to be a basic aspect of self-government. ${ }^{12}$ As Story explained, the right of petition "would seem unnecessary to be expressly provided for in a republican government, since . . . [i]t is impossible that it could be practically denied until the spirit of liberty had wholly disappeared."13 Historically, direct petitioning of Parliament or a legislature was a central feature of democratic government because it was a means of publicizing issues and setting the legislative agenda, as well as an avenue for aggrieved parties to seek relief unavailable through other channels such as the courts or the ballot box. ${ }^{14}$

8. See Smellie, Right of Petition, in 12 Encyclopaedia of the Social. ScIenCes 98-101 (1934) (tracing history and significance of right to petition); Smith, Shall Make No Law Abridging . . . : An Analysis of the Neglected, but Nearly Absolute, Right of Petition, 54 CINN. L. Rev. 1153, 1154-68 (1986) (detailed discussion of origins of right to petition, arguing it had crucial role as source of other expressive rights-speech, press, and assembly).

9. Smellie, supra note 8, at 100 . The language of the Declaration of Independence as well as most colonial charters and early state constitutions mention some form of this right. See id.; N. Smith, supra note 8, at 1173-75; see also D. Smith, The Right To Petition for Redress of Grievances: Constitutional Development and Interpretations (1971) (unpublished dissertation) (petition clause language in colonial charters and state constitutions).

10. 73 U.S. (6 Wall.) 35,44 (1867).

11. E.g., Twining v. New Jersey, 211 U.S. 78, 96-97 (1908); In re Quarles and Butler, 158 U.S. 532, 535 (1894); United States v. Cruikshank, 92 U.S. 542, 552 (1875); The Slaughter-House Cases, 83 U.S. (16 Wall.) 36,79 (1868).

12. Cf. McDonald v. Smith, 105 S. Ct. 2787, 2790 (1985) ("[T]he values in the right to petition as an important aspect of self-government are beyond question ....").

13. 2 Story, Commentaries on the Constitution of The United States 645 (5th ed. 1891).

14. In England, barons and commoners asserted the power to initiate laws by petitioning the government. In the thirteenth century, petitions from individuals and communities, addressed to the king, attempted to secure by peaceful means relief unobtainable through ordinary legal procedures. By the seventeenth century, public petitions for a change in the general law, addressed to Parliament, were an important method of propaganda and of political participation, particularly for the unfranchised. Smellie, supra note 8, at 98-100; see also C. HiLl, THE WORLd TuRNed UpSIDE Down 
Though traditionally petitioners formulated a demand or policy, collected supporters' signatures, presented the petition to the appropriate government authority, and waited for a response; ${ }^{15}$ the Supreme Court has also recognized sit-ins, demonstrations, silent protests, ${ }^{16}$ litigation, ${ }^{17}$ contacting administrative agencies, ${ }^{18}$ and political boycotts ${ }^{18}$ as activities protected by the petition clause. There is a sense in which any political act can be characterized as a petition ${ }^{20}$ - a vote is a petition to put a particular candidate into office; a speech is an oral petition signed by those who applaud it. However, certain core characteristics distinguish petitioning from other forms of political participation. First, a petition is a demand that a governmental body take a particular course of action. Whether a speech is a petition, therefore, depends on its content. Second, petitioning often involves collective activity, especially when the goal is to publicize issues and gain greater support for a cause. And third, petitioning high-

22 (1972) (petitions had this role during English Revolution: "Carefully organized petitions of support for Parliament poured in from the counties from 1641 onwards: collecting signatures for these must have been a novel and very effective way of drawing ordinary people into political action."). Likewise, petitioning was important in early American history. For example, abolitionsts devoted enormous energy to antislavery petition campaigns. See D. Smith, supra note 9, at 81-96; see also G. Barnes, The ANitslavery IMpuise, 1830-1844, at 88-150 (1933) (extensive discussion of antislavery petition campaigns). In particular, blacks who could not vote attempted to make their views and their grievances known through petitions. See R. BAILEY, supra note 2, at 43-44; see also Black Protrst 28-31, 59 (J. Grant ed. 1968) (collecting slaves' petitions, dating from 1773).

15. See Edwards v. South Carolina, 372 U.S. 229, 235 (1963) (students marching to state house with petition are exercising right to petition in its "most pristine and classic form").

16. See Brown v. Louisiana, 383 U.S. 131 (1966) (participants were petitioning for redress of grievances in three previous cases involving sit-ins and demonstrations and in present case involving silent protest).

17. See, e.g., Bill Johnson's Restaurants v. NLRB, 461 U.S. 731, 741 (1983) (access to courts is aspect of right to petition government) (quoting California Motor Transp. Co. v. Trucking Unlimited, 404 U.S. 508, 510 (1972)); see also NAACP v. Button, 371 U.S. 415, 430 (1963) ("IU]nder the conditions of modern government, litigation may well be the sole practicable avenue open to a minority to petition for redress of grievances.").

18. See United Mine Workers v. Pennington, 381 U.S. 657, 670 (1965) (efforts to lobby administrative officials protected by petition clause).

19. See NAACP v. Claiborne Hardware Co., 458 U.S. 886, 913 (1982) (states do not have right to prohibit peaceful petitioning activity such as boycott).

20. The range of activities that should be constitutionally protected by the petition clause differs from the question of how to define petitioning. Is civil disobedience, for example, petitioning activity in certain circumstances and hence subject to First Amendment analysis? Likewise, may activities described as "speech-plus," and given less protection than pure speech, be defined as petitioning? See Adderley v. Florida, 385 U.S. 39, 48 (1966) (Douglas, J., dissenting); United Mine Workers v. Illinois State Bar Ass'n, 389 U.S. 217 (1967). A related difficulty is that labor picketing, which has all the elements of a political boycott, loses petition clause protection because it is directed at a private employer. Compare Harper, The Consumer's Emerging Right To Boycott: NAACP v. Claiborne Hardware and Its Implications for American Labor Law, 93 YALE L.J. 409, 417-20 (1984) (right to petition cannot adequately protect consumer right to boycott) with Note, Labor Picketing and Commercial Speech: Free Enterprise Values in the Doctrine of Free Speech, 91 YaLE L.J. 938 (1982) (labor picketing deserves First Amendment protection). Though one commentator recently argued in favor of narrowing the range of conduct protected by the petition clause, see Smith, supra note 8 , at $1189-91$, the debate over what is constitutionally protected is not directly relevant when considering whether petitioning, generally, can bring about personal empowerment. 
lights both the responsibility of citizens to bring their grievances to the government and the corollary duty of democratic government to respond.

\section{B. Liberal and Radical Interpretations of the Right To Petition}

A traditional liberal approach to the right to petition examines whether First Amendment doctrine should be expanded to recognize the right in a greater number of situations, without fundamentally challenging or changing hierarchical social and economic structures. ${ }^{21}$ Early litigation involved the interaction between petitions and libel law in an attempt to give petitions greater protection from libel actions than speech generally. ${ }^{22}$ The Supreme Court's recent ruling that false statements made with express malice are not immune from libel actions even if contained in a petition for redress of grievances has curtailed the effort. ${ }^{23}$ In other areas, however, the petition clause has extended protection beyond the free speech guarantee. For example, the Noerr-Pennington doctrine shields attempts by businesses to combine and influence government decisionmaking from antitrust liability because this lobbying is a form of petitioning. ${ }^{24}$ In the early 1960's labor unions and the NAACP secured the right to provide legal assistance to their members on the grounds that lawsuits are petitions protected by the petition clause. ${ }^{25}$ More recently, politicallymotivated boycotts have been upheld as a legitimate form of petitioning. ${ }^{28}$ Areas of further expansion include holding that the petition clause prohibits restrictions on medical malpractice suits ${ }^{27}$ or protects gathering signa-

21. See D. Smith, supra note 9, at 281-87; see also Bachmann, supra note 3, at 22 ("The social change attorney must be prepared to protect and sustain the [First Amendment] rights that have so far been secured, and see if they can be extended."); Smith, supra note 8, at 1191-97 (right to petition not given due recognition; should have higher level of protection than speech, press, or assembly).

22. See Lake v. King, 1 Wms. Saund. 131, 85 Eng. Rep. 137 (1680); White v. Nicholls, 44 U.S. (3 How.) 266 (1845); Yancey v. Commonwealth, 135 Ky. 207, 122 S.W. 123 (1909); VanLonkhuyzen v. Daily News Co., 203 Mich. 570, 170 N.W. 93 (1918); Thorn v. Blanchard, 5 Johns. 508 (N.Y. 1809); Vanarsdale v. Laverty, 69 Pa. 103 (1871).

23. McDonald v. Smith, 105 S. Ct. 2787 (1985). For a critique of this holding, see Smith, supra note 8 , at $1184-88$.

24. See California Motor Transp. Co. v. Trucking Unlimited, 404 U.S. 508, 510 (1972) (court proceedings protected from antitrust liability by right to petition); United Mine Workers v. Pennington, 381 U.S. 657, 670 (1965) ("Joint efforts to influence public officials do not violate the antitrust laws even though intended to eliminate competition."); Eastern R.R. Presidents Conference v. Noerr Motor Freight, Inc., 365 U.S. 127 (1961) (railroad companies may unite to lobby Congress for pro-railroad laws).

25. See United Mine Workers v. Illinois State Bar Ass'n, 389 U.S. 217 (1967) (right to petition gives union right to hire attorneys on salary basis to assist members in asserting their legal rights); Brotherhood of R.R. Trainmen v. Virginia State Bar, 377 U.S. 1 (1964) (workers have right to collaborate to consider asserting rights; state cannot infringe on right of individuals to be fairly represented in lawsuits); NAACP v. Button, 371 U.S. 415 (1963) (NAACP litigation activities are forms of political expression protected by First Amendment).

26. See NAACP v. Claiborne Hardware Co., 458 U.S. 886 (1982); Missouri v. NOW, Inc., 620 F.2d 1301 (8th Cir.), cert. denied, 449 U.S. 842 (1980).

27. See Roa v. LODI Medical Group, 37 Cal. 3d 920, 695 P.2d 164, 211 Cal. Rptr. 77 (1984) 
tures for petitions at shopping malls. ${ }^{28}$ The liberal lawyer would file test case litigation to try to secure the right in these areas.

In contrast, the Critical Legal Studies (CLS) approach first questions what the liberal takes for granted-the idea that the right to petition unambiguously serves the values of human self-realization and equality. The critical approach points out how rights can be used to legitimate oppression. ${ }^{29}$ For example, with respect to the petition clause, people who have many grievances but no financial means are effectively denied the right to petition. Likewise, people who want to petition private authorities such as corporations, employers, or landlords, are not protected by the petition clause. Liberal theory cannot accommodate the right to petition as an argument for the necessity of adequately funded legal services for the poor, ${ }^{30}$ for the legality of all consumer boycotts, ${ }^{31}$ or for the expansion of

(state statute limiting size of contingency fees in malpractice cases does not violate due process clause or equal protection clause), appeal filed, 54 U.S.L.W. 3149 (U.S. Sept. 10, 1985) (No. 85-216) (raising question whether decision violates right to petition courts), appeal dismissed, $106 \mathrm{~S} . \mathrm{Ct} .421$ (1985); Cha v. Warnick, 476 N.E.2d 109 (Ind.) (state statute delaying access to courts for malpractice plaintiffs is constitutional), petition for cert. filed, 54 U.S.L.W. 3257 (U.S. Oct. 15, 1985) (No. 85328) (raising question whether statute abridges claimants' right to petition government for redress of grievances), cert. denied, 106 S. Ct. 249 (1985).

28. Compare Woodland v. Michigan Citizens Lobby, 423 Mich. 188, 194, 378 N.W.2d 337, 343 (1985) (state right to petition does not protect gathering signatures for petitions at shopping malls) with Alderwood Assocs. v. Washington Envtl. Council, 96 Wash. 2d 230, 635 P.2d 108 (1981) (state right to petition does protect petitioning at shopping center).

29. The theoretical rights critique has been summarized in a number of ways. See $\mathrm{R}$. UNGER, KNOWLEDGE AND Polrrics, 69-72 (1975) (conception of natural rights contains inherent logical contradiction); Chase, The Left on Rights: An Introduction, 62 TEx. L. REv. 1541, 1553-61 (1984) (identifying three distinct positions: one, rights embody alienation and must be rejected; two, rights can be used strategically even if concept is flawed; and three, rights can be used by those without power to gain power, while those with power use them to conceal inequality); Gabel \& Kennedy, Roll Over Beethoven, 36 STAN. L. REv. 1, 26-44 (1984) (people need social relationships that eliminate domination rather than mistaken beliefs about rights; impact of granting new rights may be to enervate political movements); Hutchinson \& Monahan, The "Rights" Stuff: Roberto Unger and Beyond, 62 TEx. L. Rrv. 1477 (1984) (legal rights are indeterminate because of contradiction between freedom and security; rights theory misrepresents individuals as egoistic and atomistic); Lynd, Communal Rights, 62 TEx. L. REv. 1417 (1984) (error to conceptualize rights as individual property); Tushnet, An Essay on Rights, 62 Tkx. L. REv. 1363, 1363-94 (1984) (rights are unstable, indeterminate, and counter-productive).

For examples of critiques of rights in specific areas of law, see Kairys, supra note 1; Klare, Labor Law as Ideology: Toward a New Historiography of Collective Bargaining Law, 4 INDUS. REL. L.J. 450, 468-80 (1981); Olsen, Statutory Rape: A Feminist Critique of Rights Analysis, 63 Tex. L. REv. 387 (1984); and Rosenblatt, Legal Entitlements and Welfare Benefits, in THE Politics of LAW, supra note 1 , at 262 .

The rights critique implies that a new framework is needed to realize the human attributes and values that rights attempt to protect. See Klare, supra note 6, at 135 ("Socialist law cannot be the mere pouring of new content into the institutional forms of liberal legalism . . . ."). But see Lynd, supra, at 1419-22 (rights rhetoric should be reworked rather than discarded). Whether or not the actual word "rights" is abandoned is less important than achieving a different conceptualization of how values can be legally protected. $C f$. Perry, Taking Neither Rights-Talk nor the "Critique of Rights" Too Seriously, 62 Trx. L. Rev. 1405 (1984) (rights-talk is dispensable feature of politicalmoral discourse).

30. Because litigation is a form of petitioning, restrictions on litigation implicate the petition clause. See supra note 17. Nonetheless, the Supreme Court has refused to conclude that where poverty 
shareholder resolution rights to non-shareholders. These propositions involve altering the social structure by redistributing income or democratizing corporate decisionmaking, efforts that go beyond liberalism. ${ }^{\mathbf{3 2}}$ In short, citizens have the right to petition only if they can afford it. Constitutional protection attaches only to grievances addressed to government, and not to petitions to other authorities. By glossing over serious limitations in the construction of the right to petition, present legal doctrine legitimates denial of the right in many circumstances. ${ }^{33}$

Present doctrine also fails to recognize that the concept of petitioning implies a government duty to respond. ${ }^{34}$ The petition clause is rooted in the idea that citizens should participate in government decisionmaking. ${ }^{35}$ In the recent Minnesota State Board for Community Colleges v. Knight ${ }^{36}$ case, however, the Supreme Court held that the petition clause does not

prevents the exercise of a constitutional right, the Constitution mandates government funded transfer payments to alleviate the problem. See Clune, The Supreme Court's Treatment of Wealth Discriminations under the Fourteenth Amendment, 1975 Sur. Cr. REv. 289. Similarly, the Court did not even acknowledge the applicability of the petition clause when it examined a federal law which effectively prohibited veterans seeking death or disability benefits from being represented by legal counsel. See Walters v. National Ass'n of Radiation Survivors, 105 S. Ct. 3180 (1985). The dissent asserted only that a claimant has a right to consult an attorney of his choice, not that the state would provide counsel. Id. at 3214 (Stevens, J., joined by Brennan \& Marshall, JJ., dissenting).

For a summary of the due process right to counsel analysis, see Lassiter v. Department of Social Servs., 452 U.S. 18 (1981). Several cases have evaluated the due process status of economic barriers to civil litigation. See Ortwein v. Schwab, 410 U.S. 656 (1973); United States v. Kras, 409 U.S. 434 (1973); Boddie v. Connecticut, 401 U.S. 371 (1971).

For a comparison of due process and right to petition analyses as a basis for a right of judicial access, see Note, $A$ First Amendment Right of Access to the Courts for Indigents, 82 YALE. L.J. 1055 (1973). The author stops short of claiming that the right to petition requires the government to provide counsel for indigents in civil cases. Id. at 1066-67. A more recent student note which argues that restricted access to courts violates the petition clause concludes not that all civil litigants should be provided with counsel, but that attorney licensure is unconstitutional. See Note, On Letting the Laity Litigate: The Petition Clause and Unauthorized Practice Rules, 132 U. PENN. L. REv. 1515 (1984) [hereinafter Note, On Letting the Laity Litigate].

31. See Harper, supra note 20 , at $417-20$ (right to petition only protects consumer boycotts aimed at obtaining particular government action, not those intended to influence private parties).

32. I am only claiming that the changes mentioned go further than what is generally understood as liberalism. As one theorist comments, "[l]iberalism is an elusive label . . . B" Baker, The Process of Change and the Liberty Theory of the First Amendment, 55 S. Cal. L. Rev. 293, 304 (1981).

33. Cf. Kairys, supra note 1, at 164 ("The ideology of free speech . . . is used to validate and legitimize existing social and power relations and to mask a lack of real participation and democracy.").

34. The duty to respond may or may not be an element of a liberal approach. Compare D. Smith, supra note 9, at 88-103 (summary of historical debate over whether denying duty to respond nullified right to petition) and Note, On Letting the Laity Litigate, supra note 30, at 1525 (for right to petition to be meaningful, "it must mandate some minimum level of state receptivity to citizens' grievances") with Smith, supra note 8 , at 1190-91 (right to petition should not be expanded to include right to have government consider petitions).

35. Framers of the petition clause intended that direct petitions to Congress should be a means of participation in government decisionmaking. James Madison stated: "The people may therefore publicly address their representatives, may privately advise them, or declare their sentiment by petition to the whole body; in all these ways they may communicate their will." 1 ANNALS OF CoNGRESS 766 (Gales ed. 1834) (Statement of J. Madison, Aug. 15, 1789).

36. 465 U.S. 217 (1984). 
require the government to listen or respond to petitions. ${ }^{37}$ If the government has no duty to consider or respond to petitions, the right to petition contributes little to democratic decisionmaking. Indeed, the right would guarantee no more than freedom of speech. Defining the right to petition as merely a right to come forward is similar to saying that citizens can vote but candidates with the most votes will not necessarily take office, or that plaintiffs can file lawsuits but defendants have no duty to answer.

The duty to respond is essential to make petitioning a means of participation in democratic decisionmaking. In Minnesota State Board, Justice O'Connor tacitly acknowledged that petitioning, as construed by the Court, cannot be a method of meaningful participation in political processes: "Disagreement with public policy and disapproval of officials' responsiveness . . . is to be registered principally at the polls." ${ }^{38}$ However, as one dissenting opinion argued, "the First Amendment was intended to secure something more than an exercise in futility." ${ }^{39}$ A revitalized right to petition including some form of a duty to respond would give citizens the opportunity to participate more directly in government decisions. ${ }^{40}$ Indeed, Roberto Unger's concept of destabilization rights incorporates the right to petition, with a corresponding government duty to respond, into a vision of an ideal democratic society. ${ }^{11}$

What does the CLS approach to the petition clause mean for the radical lawyer? She must develop both a theory which demonstrates how the values behind the right to petition can be better achieved through participatory social structures and institutions, and a practice which helps shape and realize that theory. ${ }^{42}$ Although liberal theory and current petition clause doctrine are flawed, it is the people in society whose class interests are in maintaining present social structures who perpetuate limitations on petitioning rights, not the theory itself. The radical lawyer should focus on enabling poor and powerless people to petition rather than on changing legal doctrine. Because lawyers frequently seek redress of grievances, ${ }^{43}$ they are in a unique position to further the realization of the right to petition.

\footnotetext{
37. Id. at 285 .

38. Id.

39. Id. at 308-09 (Stevens, J., dissenting).

40. The majority in Minnesota State Board believed that a duty to respond would be impossible to define and implement. Id. at 284. Nevertheless, interpreting the extent of a reasonable duty to respond is analogous to and should be no more difficult than interpreting a duty of care.

41. See. Unger, supra note 5, at 600, 611-15.

42. See supra note 6.

43. See Cahn \& Cahn, The War on Poverty: A Civilian Perspective, 73 Yale L.J. 1317, 1321 (1964) ("The lawyer's function is essentially that of presenting grievances so that those aspects of the complaint which entitle a person to a remedy can be communicated effectively and properly to a person with power to provide a remedy.").
} 


\section{The Marxist Critique of Law and Lawyers}

\section{A. The Classical View}

Classical Marxism views law simply as a tool the ruling class uses to perpetuate an oppressive social system. ${ }^{44}$ Political leftists therefore question the very possibility of being a radical lawyer. Radical groups have concluded that lawyers are necessarily part of the oppressive legal machinery, sometimes refusing to grant them membership in their organizations. ${ }^{48}$ More commonly, they are reluctant to seek legal help in fighting courtroom battles. ${ }^{46}$ Radical lawyers themselves have taken various defeatist or minimalist positions. If not confused about what their role should be, ${ }^{47}$ they may believe that whether they win or lose the case, the net effect of their work is simply to accommodate the client to the legal system, thereby reinforcing and legitimating that system..$^{48}$ Alternatively, they may believe that the most they can do is to stop excesses of legal oppression in some individual cases. ${ }^{49}$ Scholars and practitioners alike argue that law reform has not and cannot bring about fundamental social change, ${ }^{50}$

44. This view has also been called "crude", "orthodox", or "scientific" Marxism. See, e.g., Gabel \& Harris, supra note 6, at 369 \& n.1 (summary of orthodox Marxist view). It starts from the base/ superstructure analysis of society which characterizes the state as an instrument of class power. Marx, Marx on the History of His Opinions (Preface to A Contribution to the Critique of Political Economy), in The: MARX-Engkis ReAder 4-5 (R. Tucker ed. 1978).

45. See, e.g., Rabinowitz, The Radical Tradition in the Law, in The Politrcs of LAw, supra note 1 , at 310, 312-13 (International Workers of the World convention refused to admit lawyer).

46. See, e.g., M. Jamks, The People's Lawyers 166 (1973) (communist party believed lawyers should not join Civil Rights Movement because they would hurt movement); Finman, OEO Legal Service Programs and the Pursuit of Social Change: The Relationship Between Program Ideology and Program Performance, 1971 WIS. L. REv. 1001, 1010 \& n.18 (poverty community organizers and activists think resort to lawyers will impede organizational efforts); Guardian, Mar. 5, 1986, at 4, col. 2 (defendants in political trial represent themselves).

47. Confusion over their role in society was expressed by radical lawyers interviewed in $M$. JAMFS, supra note 46; see, e.g., id. at 210 (interview with Michael Tigar).

48. There is an ambiguity here. One must ask: In whose eyes is the system legitimated? Abel suggests that legal aid legitimates the system in the eyes of those who enjoy wealth, power, and status by comforting them that society has achieved procedural justice. See Abel, Law Without Politics: Legal Aid Under Advanced Capitalism, 32 UCLA L. REv. 474, 601-06 (1985); see also Abel, Lawyers and the Power To Change, 7 LAw \& PoL'Y 13 (1985) (success of progressive lawyers in delivering legal services potentially contributes to legitimation of law and lawyers).

49. See Kenyatta, Community Organizing, Client Involvement, and Poverty Law, 35 MoNTHLY REv., Oct. 1983, at 18, 23 (poor need assistance of lawyers to mitigate deprivation, abuse, and repression); Sparer, A Friendly Critique, supra note 6, at 574 (lawyers can help some oppressed individuals); see also Menkel-Meadow, Legal Aid in the United States: The Professionalization and Politicization of Legal Services in the 1980's, 22 OsGoODE HALL L.J. 29, 51-52 (1984). Though most of the essays in LAw AGainsr THE PeOPLE (R. Lefcourt ed. 1971) conclude that the lawyer is peripheral to social change movements, they do describe a model of radical lawyering in which the lawyer acts as a buffer between social activists and government authorities, including the judiciary, that try to obstruct change. For a more systematic development, with extensive documentation, of the role of a "movement lawyer" who provides legal services to activists, see Hakman, Political Trials in the Legal Order: A Political Scientist's Perspective, 21 J. PuB. L. 73, 102-11, passim (1972).

50. See B. Garth, Neighborhood Law Firms for the PoOR 172-78 (1980) (law reform cannot bring new effective rights and entitlements to poor); J. HaNDLER, Social MOVEMENTS AND THE. Legal. SyStem 232-33 (1978) (law reform will not achieve basic social change); H. StumpF, 
that the system minimizes legal victories, ${ }^{51}$ and that legal assistance for the poor, while securing some gains, is inherently limited. ${ }^{52}$

\section{B. The Neo-Classical View: A Theory of Empowerment}

While agreeing with the pessimistic conclusion that the legal system cannot be used as a means for achieving radical social change, neoclassical Marxists maintain that Marx did not view law as purely instrumental, but rather emphasized its ideological and mystifying functions. ${ }^{83}$ Thus, law is conceived more broadly as helping to create and articulate class relationships. ${ }^{54}$ If a lawyer can use her position to work against hierarchy and personal domination, then she is contributing to social change. The ideal practice, therefore, encourages clients to enter non-hierarchical relationships while they challenge or withdraw from hierarchical ones. The lawyer contributes to social change by facilitating individual and collective empowerment. ${ }^{55}$

Various radical theorists have recently outlined a theory of practice

Community Pol.t'ics and Legai. Services 273-81 (1975) (law reform cannat address fundamental problems); Bachmann, supra note 3, at 29-33 (public interest movement cannot change society). But see McDougall, The Role of the Black Lauyer: A Marxist View, 7 Bl.ACK L.J. 31 (1980) (arguing that black lawyers can be agents of social change by pursuing law reform and rights-enforcement).

51. Galanter, Why the 'Haves' Come Out Ahead: Speculations on the Limits of Legal Change, 9 LAw \& Soc'y Rev. 95, 149 (1974) (law reform "can be readily absorbed without any change in power relations"); see also F. Piven \& R. Cloward, Poor Peoples' Movements 301-07 (1979) (welfare department's response to campaign for special grants was to abolish program); Gabel \& Harris, supra note 6 , at 375 \& n.12 (Supreme Court can respond to destabilizing social movements by creating bodies of law that appear to recognize demands but in fact validate conditions that movement sought to transform).

52. See Abel, Law Without Politics, supra note 48, at 614; see also J. KATz, Poor Prople's LAWYERS IN TRANSITION 194 (1982) (legal assistance furthers administrative segregation of poor); Lord \& Smith, The New Black Lawyer as Community Builder, 7 Bl.ACK L.J. 62 (1980) (black lawyers in legal services programs are limited in what they can do to change status quo, even through impact litigation). Lord and Smith advocate that black lawyers encourage and assist grass roots organization of housing, food, health care, day care, and other cooperatives that respond to the concrete needs of black people. This institution-building role is complementary to the empowerment theory outlined here; indeed, they write: "The delivery of legal services to black people must ultimately be defined and controlled by the black community. [Black lawyers must] . . . create institutions designed to deliver legal services in a manner which would impart power to black people." Id. at 68 .

53. See Bachmann, supra note 3, at 33; Gabel \& Harris, supra note 6, at 370 n.1 (citing Marx, On the Jewish Question, in The MARX-Engels ReADER 26 (R. Tucker ed. 1978)) (Marx emphasized mystifying role of law).

54. Recent literature on neo-Marxist theories of the state and of law is listed in Klare, supra note 6 , at 123-24 nn.1 \& 3. For a summary of neo-Marxist legal theory, see Gabel \& Harris, supra note 6, at 371-74, and for recent criticisms of the classical Marxist view of law and lawyers see Bachmann, supra note 3, at 33-36; Gordon, supra note 7, at 284-90; and Rabinowitz, supra note 45, at 312-13.

55. This thesis tries to follow Karl Klare's command:

We must begin to see our work, our relationships to our clients, our self-definition in counseling and in the courtroom, as itself part of the process of articulating and foreshadowing the legal forms of the future. The fact that we must live and work within alien institutions we do not control . . . ought not prevent us from conceiving of our own participation in the legal process . . . as an experiment in the possibility of our freedom.

Klare, supra note 6 , at 135. 
which advocates using the legal system to increase people's sense of personal and political power ${ }^{86}$ Gabel and Harris identify three general ways to accomplish this: 1) by developing a lawyer-client relationship of genuine equality and mutual respect; 2) by demystifying the symbolic authority of the state in courtroom proceedings; and 3) by reshaping the way legal conflicts are characterized to bring out their social, economic and political foundations. ${ }^{57}$ They argue that all legal cases, even routine matters, are potentially empowering ${ }^{68}$ but caution that an empowerment approach will have an impact on society as a whole only if lawyers as a group organize themselves around the realization of its goals. ${ }^{58}$

A number of lawyers engaged in social change have embraced elements of empowerment theory, though not always deriving them from a wider socialist political analysis. C.B. King, the only black lawyer in Albany, Georgia during the intensive civil rights activities there in the early 1960 's, had previously engaged in demystifying the symbolic authority of the state when he first appeared in court in $1954 .{ }^{\circ 0}$ To ensure that he would not jeopardize the interests of his client, he waited until the case was finished, and then refused to move back to the area of the courtroom to which blacks were relegated. ${ }^{\text {B1 }}$ Writing in 1977, Gary Bellow urged legal assistance attorneys to discuss with clients the specific political choices in the handling of their cases as it would be "far more likely to empower and educate them than continuing the myth that their cases are being resolved by an apolitical body of rules in an apolitical legal system." ${ }^{82}$ Lawyers representing poor and oppressed people in England,

56. See Gabel \& Harris, supra note 6. For descriptions of Paul Harris' law collective which illustrate how he implements his theory, see M. JAMES, supra note 46, at 220-25; Harris, The San Francisco Community Law Collective, 7 LAw \& PoL'y 19 (1985); Harris, Law Collectives as Power Bases, 2 New Dirkecitions in Legal Services 164 (1976).

57. Gabel \& Harris, supra note 6, at 376. Bachmann criticizes Gabel and Harris' work, arguing that empowerment is only a partial solution because of the problem of force, and that demystifying symbolic authority does not help clients because they are not taken in by courtroom folderol. Bachmann, supra note 3, at 36-44; see also Bachmann, Bachmann \& Weltchek: ACORN Law Practice, 7 LAW \& PoI.'Y 29, 41 (1985) (Bachmann thinks that people's organizations, not lawyers, effect change. He states: "[T]he lawyer who seeks to transform social relationships within the law office and the courtroom is trying to start the revolution in the wrong place and in the wrong way."); $c$. Lynd, supra note 29, at 1419 ("To invite ourselves to think of power rather than of rights necessarily extends the same invitation to others, hostile to our utopias, who have much more power than we do.").

58. Gabel \& Harris, supra note 6 , at 379.

59. Id. at 376, 398-99.

60. See M. JAMEs, supra note 46 , at 294-96.

61. Id. at 295. King's courtroom protest is noteworthy because it demonstrates the potential conflicts between the client's immediate interests and the lawyer's political goals. King paid a price for his actions: Six years later he was beaten with a club by the sheriff whose commands he ignored his first day in court. Id. at 296; $c f$. Gabel \& Harris, supra note 6, at 399-402 (examples of lawyers politicizing courtroom).

62. Bellow, Turning Solutions into Problems: The Legal Aid Experience, 34 NLADA BrIEFCASE 106, 121 (1977). 
Canada and Latin America have concentrated on providing clients with the knowledge and resources to participate in local policy issues, ${ }^{63}$ helping people to acquire genuine power over all aspects of their lives, ${ }^{64}$ and empowering those on the outside. ${ }^{65}$ These examples demonstrate that while a handful of people have concluded from their own experiences that a lawyer should aim to empower clients, the need for a unifying and well developed empowerment theory of legal practice still exists.

None of the competing theories behind government legal services programs has considered empowerment to be its central and guiding aim. ${ }^{66}$ Moreover, government policies impose legal restrictions on the political activities of legal assistance lawyers. Lobbying, community organizing, publicizing cases, attending demonstrations, assisting boycotts or picketing, and attempting to influence administrative agencies are all forbidden activities for legal services attorneys. ${ }^{67}$ Yet these activities are protected elements of the right to petition, ${ }^{68}$ as well as fundamental to the lawyer's duties under the empowerment theory elaborated here. ${ }^{8 \theta}$ Thus, legal constraints would undoubtedly hinder an attorney in a government-funded legal services program who wished to carry out the kind of practice suggested here. This is a significant limitation on the potential of the empowerment approach to reach poor clients because of the dominant role that government-funded legal services programs play in representing poor people throughout the United States. ${ }^{70}$

63. See Stephens, Law Centres, Citizenship, and Participation, 7 Law \& Pol'y 77 (1985).

64. See Martin, Law Union of Ontario, 7 LAw \& PoL'y 51, 55 (1985).

65. See Thome, New Models for Legal Services in Latin America, 6 Hum. Rrs. Q. 521, 525 (1984) ("If overall political conditions are supportive, as they may be in some countries, and if legal services programs are properly staffed and organized, then lawyers for the poor could help empower those now on the outside.").

66. See, e.g., E. Johnson, Justick and Reform 21-35 (1978) (discussion of competing ideas in formulation of OEO Legal Services Program; some neighborhood law firm advocates intended to involve poor people in social services policy-making but did not espouse empowerment as developed here); Breger, Legal Aid for the Poor: A Conceptual Analysis, 60 N.C.L. REv. 282 (1982) (aim of legal aid should be access to courts for poor people, not increased welfare of poor community); Finman, supra note 46, at 1054 (legal services programs have three ideologies: advocate social change; meet individual client need and advocate social change; meet client need only); Menkel-Meadow, supra note 49 (reviewing different aims of legal services for poor in four historical periods). But see Rothstein, The Myth of Sisyphus: Legal Services Efforts on Behalf of the Poor, 7 U. Mich. J.L. REF. 493, 512-15 (1974) (some programs have attempted to make the poor self-sufficient and encourage community autonomy).

67. See 42 U.S.C. $\$ 2996 f(a)(5)-(6)$, (b) (1982); 45 C.F.R. $\$ 1612$ (1985) (federally funded poverty lawyers precluded from engaging in any political activity); see also Houseman, Community Group Action: Legal Services, Poor People and Community Groups, 19 Clearinghouse Rev. 392, 398-99 (1985) (discussing effects of restrictions on activities of legal services attorneys).

68. See supra notes $15-19$ and accompanying text.

69. See infra notes 99-131 and accompanying text.

70. See Legal Services Corporation Reauthorization: Hearings on H.R. 2506 and H.R. 3480 Before the Subcomm. on Courts, Civil Liberties, and the Administration of Justice of the House Comm. on the Judiciary, 97th Cong., 1st Sess. 682 (1981) (report of Legal Services Corporation that it "provides funds to almost all legal aid programs in the country"). 


\section{Definition of Empowerment}

It is important to understand what radical theorists mean by empowerment. ${ }^{71}$ The concept's meaning varies according to one's underlying descriptive and normative views of the nature of power in society. ${ }^{72}$ Rooted in democratic socialist values, empowerment is a process by which individuals develop a sense of personal responsibility for the fundamental decisions that most affect their lives, and results ultimately in the democratization of economic and political decisionmaking. ${ }^{73}$ Empowerment does not refer to a group as a whole gaining greater influence, as would be suggested by a pluralistic model of political life, nor does it mean the supremacy of one individual over another, as in a marketplace model. Rather it involves a change in consciousness and social relations so that people see themselves as able to join, and actually do join, in making decisions, along with their community, which affect their lives in important ways. Empowerment-the opposite of alienation ${ }^{74}$-cannot be achieved by a simple attitude change; it depends, to a certain extent, on actual participation in a political movement or some other collective activity by which people try to influence decisions that affect their lives. ${ }^{75}$

Activist Bernice Reagon gives an eloquent account of how she was empowered by the Civil Rights Movement:

What I've had since the Civil Rights Movement is a better knowledge of who I am in this society, an understanding of my power as a person to stand and speak and act on any issue that I feel applies to me in some way and therefore to other people. . . .

I learned that I did have a life to give for what I believed. Lots of

71. Roberto Unger claims that the most striking defect of liberal society is that it has not "developed rightholding into active empowerment over the terms of social life . . . Unger, supra note 5, at 672 . But he does not present a clear definition of what he means by empowerment.

72. For example, Bryant Garth, who has conducted a comparative study of activist, social-reform oriented lawyers for the poor in eight countries, embraces a more traditional pluralistic theory of politics, and describes a model of empowerment that requires coalition building. B. GARTH, supra note 50. Specifically, though Garth argues that lawyers should concentrate on organizing and serving groups of poor people, he emphasizes the exigency of political positioning. "One can question how much reform can be accomplished by local groups of poor persons lacking any real economic and political power. Poor persons cannot succeed in making lasting gains unless they can find common ground with middle-class groups, labor unions, and the like." Id. at 192.

73. C.B. MacPherson articulates an ideal of power compatible with this concept in C.B. MACPherson, Problems of a Non-Market Theory of Democracy, in Democratic Theory, Essays in Retrieval. 39, 52-57 (1973). I do not claim that, historically, empowerment theories have always been drawn from a socialist perspective. See supra notes $60-65$ and accompanying text.

74. "Alienation" is used here to refer to a person's sense that he has no control over his fate or the society in which he lives. See Marx, supra note 44 , at $43-46$.

75. Empowerment is a change of consciousness that depends to some degree on having successful experiences of participation in decisionmaking. See D. LouIS, AND WE ARE Not SAved 116-17, (1970) (youth in Civil Rights Movement underwent transition to independent decisionmaking). But it is possible to be empowered by an experience of defeat. See infra note 91. 
people don't know that; they feel they don't have anything. When you understand that you do have a life, you do have a body, and you can put that on the line, it gives you a sense of power. ${ }^{76}$

Certain young people involved in the Civil Rights Movement, like Bernice Reagon, initially viewed power negatively as "that which enabled some people to make decisions for others, something they were fighting to eradicate." 77 This concern led them to develop the idea of personal empowerment as a goal of political activity. ${ }^{78}$ Empowerment comes from recognizing the important role one has in working with others, not from dominating them. The Student Non-Violent Coordinating Committee expanded the idea of empowerment to encompass a theory of leadership. ${ }^{79}$ If local people were empowered, they could carry on the struggle without outside organizers. ${ }^{80}$ Instead of mobilizing people around a charismatic leader, or even a few leaders, radical movements must encourage and build local "group-centered" leadership among the masses. ${ }^{81}$ One important aim of this concept of organizing is to democratize the movement. ${ }^{82}$ Empowerment as a process of personal development that must occur in the context of collective activity was central to this theory of leadership. Ella Baker, an early proponent of group-centered leadership, stated: "Instead of 'the leader'-a person who was supposed to be a magic man-you would develop individuals who were bound together by a concept that benefited larger numbers of individuals and provided an opportunity for them to grow into being responsible for carrying on the pro-

76. Interview with Bernice Reagon, a participant in the Albany Movement, in ThEY Should Have Served That Cup of Coffee 29 (D. Cluster ed. 1979). See generally J. Forman, The Making of Bi.ack Revolutionaries 260-62 (1972) (explaining Bernice Reagon's role in Albany movement); A. Morris, The Origins of The Civil. Rights Movrment 239-50 (1984) (deseription of Albany Movement).

77. D. Louis, supra note 75 , at 13.

78. See, e.g., Student Non-Violent Coordinating Committee (SNCC) Staff Memorandum, "What is SNCC?" (1964), reprinted in The American Left, Radical. Polmicical. Thought in 7he TWENTIETH CENTURy 361, 363 (L. Baritz ed. 1971) ("IW]e want a world where people have control over the decisions that most affect them."); interview with Jean Smith, in They Should Have SERved That Cup of Coffee, supra note 76, at 32 (SNCC wanted to maximize potential of local people).

79. The group-centered theory of leadership was not the only view, even within SNCC. For a discussion of competing ideas of leadership in the movement, see C. Carson, IN STRUGGLE, SNCC AND the Bl.ACK AwAKENING OF THE 1960's, at 138-40 (1981); J. Forman, supra note 76; $A$. MORRIS, supra note 76.

80. J. FORMAN, supra note 76 , at 237-38.

81. See A. Morris, supra note 76 , at 104.

82. Indeed, some leaders of the Albany Movement were opposed to Martin Luther King, Jr. coming to Albany because they preferred to keep the movement's leadership, goals, and tactics under local control. See D. Lewis, King: A Biography 147-70 (2d ed. 1978). Democratizing the movement was important because of the need to avoid conflict between organization and community goals. See D. Louis, supra note 75 , at 268. Another aim was to minimize internal struggles for the leadership role. A. MoRRIS, supra note 76, at 104. 
gram."83 Through empowerment people became capable of engaging in struggles for change. ${ }^{84}$

As the group-centered theory of leadership suggests, empowerment is valuable for radical social change in several ways. First, to create a democratic movement, a majority of people must be convinced not only that change is necessary and desirable, but also that they rightfully have the power to effect it. ${ }^{85}$ When people feel powerless, they accept and accommodate social conditions that they realize are oppressive, inhumane, or simply contrary to their best interests because they believe that they can not do anything about them. ${ }^{86}$ Overcoming this sense of powerlessness is necessary to stimulate participation in a democratic movement. Moreover, empowerment is necessary to create and sustain the democratic institutions that are a central element of socialist positive programs. ${ }^{87}$ Experience in the United States with collectively owned and managed work enterprises suggests that workers must have a democratic consciousness to participate effectively in worker-controlled organizations. ${ }^{88}$ To maintain non-hierarchical institutions, people must accept the responsibility of participating in collective decision-making. Thus, empowerment is necessary to bring about a socialist movement and to maintain the more democratic institutions that socialists hope to create.

This is not to imply that empowerment is an unqualified good. There is no way to guarantee that once empowered, once willing and able to participate in decisions about issues that have an important impact on their lives, people will use that power in beneficial ways. Participants in the Givil Rights Movement were aware of this problem. For example, Bob Moses, a SNCC organizer in Mississippi, expressed concern that "[W] people rise up and change their status, usually somewhere along the line ... they get involved in subjugating . . other people."89 An example

83. A. MORRIS, supra note 76 , at 104.

84. For other examples of local people whose participation in civil rights activities made them aware of their power to change events, see H. RaInes, MY Soul is Rasten (1977) (interviews of Civil Rights Movement participants); see also S. Evans, Personal Politics 56-57 (1979) (working to make people aware of their own power and to expand decisionmaking process was itself empowering). The empowerment of women in the Civil Rights Movement was one factor in the later development of the Women's Liberation Movement. Id.

85. See Gabel \& Harris, supra note 6, at 371-79.

86. Lerner, Surplus Powerlessness, Soc. Pol.'Y, Jan.-Feb. 1979, at 18.

87. Unger's theory of organic groups, the third and final part of his positive argument, contains his vision of a better society. It includes diminishing domination, an actualization of human nature, and a community based on collective decisionmaking. See R. UNGER, supra note 29, at 236-95. A brief, more accessible statement of a similar democratic socialist vision is in Sparer, A Friendly Critique, supra note 6 , at 569-71.

88. See Rothschild-Whit, The Collectivist Organization: An Alternative to RationalBureaucratic Models, 44 AM. Soc. Rev. 509, 521-22 (1979) (democratic consciousness necessary for effective workers' control).

89. Interview with Bob Moses, in R. WARren, Who Speaks for THe Negro? 95-96 (1965). 
might be a community group organized to boycott a particularly unscrupulous business that, when successful, continues to use similar tactics against honest merchants. However difficult this problem of abusing power may be, it does not justify keeping people who are powerless and alienated from taking steps to attain greater control over their lives.

\section{What Petitioning Adds to the Empowerment Theory}

Mutual respect, demythologizing the legal system, and characterizing cases in political terms are important techniques to avoid domination in the lawyer-client relationship. ${ }^{90}$ These techniques also will help a client recognize the political nature of his problem and of the law itself if he has not done so already. Empowerment requires a further step-that people actually gain political power and have greater control over their lives. Whether or not a lawyer's work will result in empowerment, either of an individual client or an entire community, depends on a number of factors, some of which are outside the lawyer's control. ${ }^{91}$ However, a lawyer can encourage empowerment through a variety of means, notably by encouraging petitioning. ${ }^{22}$

Petitioning, as broadly conceived, is empowering in four ways: 1) it can be a catalyst for further political organization and a way to build a movement with far-reaching goals by starting with smaller goals; 2 ) it requires local involvement; 3) it focuses on collective activity; and 4) it suggests a range of options for seeking redress. The following discussion examines how petitioning activity during the Civil Rights Movement had these characteristics and the conclusions they suggest about the proper practices and goals of a radical lawyer.

90. These are Gabel and Harris' recommendations. See supra text accompanying notes 57-59.

91. Petitioning activity could reinforce feelings of alienation and powerlessness if it has no effect whatsoever. In the student and anti-war movements, winning limited goals led activists to redefine the criteria of success "in such a way as to guarantee that they would end up being one down, in a way that would accentuate how little they had accomplished and how overwhelming were the tasks yet to be achieved." Lerner, supra note 86 , at 19 . Failure to bring about change through petitioning activities that involve a high level of commitment may cause frustration and leave people feeling angry, helpless, exhausted, and even more powerless. See H. RAINes, supra note 84, at 259, 273 (examples of Civil Rights Movement participants experiencing "burn out").

This argument must be qualified because much turns on how and why the petitionirg effort fails. After a defeat people may realize that although they did not achieve their particular goal, they did accomplish a number of things. See A. MORRIS, supra note 76, at 250 . After being involved in political activity, people should realize that they can try to influence decisionmaking processes, rather than passively accept decisions that are made for them. See D. LEwIS, supra note 82, at 169 (despite defeat in Albany Movement, "Albany blacks would never again accept less than the total achievement of their legal and human rights."). They may learn important lessons from a defeat that will encourage them to do things differently the next time. $\mathcal{D}$. Louis, supra note 75 , at 8 (Civil Rights Movement failed ultimately, but established viable methods of accomplishing change).

92. In the following discussion, I do not mean to imply that petitioning for redress of grievances is the only method of empowerment. For example, community economic development is a potentially empowering process which lawyers can assist. See Lord \& Smith, supra note 52. 


\section{A. A Catalyst}

In many instances during the Civil Rights Movement, the writing and circulation of a petition was the first step activists took to mobilize community ${ }^{93}$ support and to initiate protest. ${ }^{94}$ Boycotts, sit-ins, lawsuits, and attempts to register to vote were also tactics used to make demands. ${ }^{95}$ When such action was taken, other people in the community overcame their fears and feelings of powerlessness to support the movement. ${ }^{96}$ If this seems an obvious method of stimulating protest, consider that alternative approaches might have been taken, such as forming a mass membership organization prior to making any outright challenge. ${ }^{97}$ Petitioning publicized issues and enabled people to set specific goals, such as obtaining school buses, desegregating lunch counters, or registering to vote, even though their ultimate goals were broader. ${ }^{98}$ Success in one area was a catalyst for further efforts.

A lawyer will bring about empowerment when she clarifies goals for a client or client-community. Lawsuits are one type of petition that can specify grievances, even if the community's goals go beyond what the current legal system will deliver. Lobbying, attending public hearings, organizing boycotts, and other forms of petitioning are actions the lawyer can facilitate to build support for social change movements. ${ }^{99}$ When view-

93. Movement participants tried to create a community as an ideal of non-hierarchical society. D. Louts, supra note 75, at 65-75; S. EvaNs, supra note 84, at 41-42, 94-95. By using the term here, I do not intend to imply that urban, low income people constitute a fully cohesive group with easily identifiable concerns and interests. On the other hand, creating or choosing a community to represent is not so difficult as to be impossible. See, e.g., Harris, Law Collectives as Power Bases, supra note 56, at 164-65 (defining and choosing client community are crucial and manageable tasks).

94. See, e.g., S. Evans, supra note 84, at 35 (circulating petition sparked political involvement of students); R. KI.U(GrR, Simpi.E. Jusrick 15-16 (1976) (petition to school board initiated case which eventually became part of Brown $v$. Board of Education litigation).

95. D. Louis, supra note 75, at 453-59 (example of civil rights housing campaign that began with complaint to city authority and other legal action); $A$. MORRIS, supra note 76 , at $48-49$, passim (examples of boycotts, protests, and sit-ins mobilizing local communities); H. RaINFs, supra note 84, at 43-51 (court case carefully selected to trigger Montgomery Bus Boycott); $c f$. D. LEwIS, supra note 82, at 143-44 (SNCC's first step in Albany was to gain confidence of local community before starting demonstrations, but freedom rides catalyzed city's black leadership to organize further). The Albany Movement's demands were specified in a petition of grievances which the city commissioners refused to consider. Id. at 155.

96. See Moses, Letter to Northern Supporters, in Black Protest 299, 300 (J. Grant ed. 1968) 、 (describing process of convincing people they must make demands and protest to escape poverty). On the need for organizers of the Civil Rights Movement to overcome local people's fears and persuade them that they could change the deeply segregated and oppressive society, see H. RAINEs, supra note 84, at 233-90.

97. See F. Pivin \& R. Cloward, supra note 51, at 278-80.

98. See D. Louis, supra note 75 , at 15 ("Many began by being committed perhaps only to the integration of a particular lunch counter or school and through the experience gained in setting about and accomplishing this immediate goal, the wider, more fundamental issues then became better defined and the commitment grew."). See generally H. ZinN, SNCC: THE NEw ABolitionists 216-41 (1965) (discussion of SNCC's goals).

99. See, e.g., Bachmann, supra note 3, at 47-50 (demonstrations, petitions, rallies, lawsuit, and 
ing her actions as assisting a client to petition for redress, and knowing that a petition can be a catalyst for further action instead of an end in itself, the lawyer should not only politicize cases and try to encourage community organizing, but also evaluate the potential for making the petition a stepping stone to other actions. For example, a lawyer can encourage tenants who organize in response to eviction proceedings to work together on more long-term solutions to their housing problems. The lawyer can give the group space for meetings, talk about what has been done in other localities, or find out how other people in the community have handled similar problems. ${ }^{100}$ This is not to suggest that a case without such catalytic attributes must be refused, but only that the lawyer should always explore the possibilities of further action. A petition stimulates further political action when it is used to politicize issues, identify a group of people with a common interest, and specify an immediate goal.

This method of encouraging social change may sound gradual and incremental, rather than revolutionary, but the speed and type of change depends on the contents of the petition. An underlying assumption here is that democratic principles require social change movements to begin with what people currently want. ${ }^{101}$ To this extent, new institutions and social structures are inevitably shaped by struggle within and over present ones. ${ }^{102}$ Petitioning can serve an important function in a movement for social change by stimulating protest activities with a definite goal.

\section{B. Local Control}

Ensuring local control of the petitioning process is equally important for a lawyer as the attempt to make petitioning activity a catalyst. Petitioning is empowering only when it encourages people to be involved directly in political struggles. Most of the protest activities during the Civil Rights Movement required the participation of local people. ${ }^{103}$ Voter registration drives required residents to attempt to register. ${ }^{104}$ Boycotts required the community to stop patronizing the target store or company, as

public hearings were all part of campaign to revoke utility franchise).

100. For other examples of what lawyers can do to encourage clients along these tines, see Stephens, supra note 63 , at $86-90$.

101. For example, students in SNCC in the early years had a sophisticated political awareness with ultimate goals of radical social change, but focused on issues that would provoke a broad consensus: voter registration and public accommodations. See C. CARSON, supra note 79, at 50-55.

102. Cf. Unger, supra note 5 , at 614 (doctrines proposed for radically different society are extension of present law and legal thought).

103. A. MORRIS, supra note 76 , at xii, 282-86 (study demonstrates how indigenous base created and sustained Civil Rights Movement).

104. See, e.g., H. RAINES, supra note 84, at 249-55 (experience of Fannie Lou Hamer when attempting to register to vote); S. BELFRAGE, FreEDOM SuMMer (1966) (description of 1964 voter registration drive in Mississippi). 
well as to cooperate in developing alternative means of getting groceries or rides to work. ${ }^{105}$ Even sit-ins and freedom rides, which sometimes involved non-Southerners, required the support of local people to provide safe houses for battered students, or communication between communities. ${ }^{108}$ The Freedom Summer Project relied heavily on local black communities to provide housing for volunteers. ${ }^{102}$ In these instances, local people could have stopped the petitioning activity altogether by withdrawing their support.

The nature of local people's involvement in the Civil Rights Movement was also remarkable in that the situation demanded a significant commitment on their part. Often, signing a petition is a single, isolated act, involving little political activity beyond a cursory conversation with the person soliciting the signature. Other types of petitioning, such as attending a demonstration, can likewise entail minimal participation. In contrast, southern blacks in the fifties and sixties who participated in petitioning activities suffered harassment, intimidation, and loss of their homes, their jobs, and even their lives. ${ }^{108}$ Signing a petition in those circumstances demonstrated a deep commitment. For veteran movement people, commitment meant a willingness to sacrifice whatever was necessary to achieve their goals. ${ }^{109}$

This experience demonstrates that committed involvement in petitioning activity is necessary to make the activity empowering. Likewise, clients will only be empowered if they have a decisive and active role in the lawsuit, lobbying effort, administrative appeal, or other activity they choose to pursue in seeking redress of their grievances. Emphasizing client participation has two important implications. It requires a reconceptualization of the lawyer-client relationship and it alters the tasks that a lawyer should perform.

The dominant professional vision of the lawyer-client relationship assumes that clients are able to communicate their interests to the lawyer who will act as their agent. ${ }^{110}$ Commentators have questioned the applica-

105. See A. MORRIS, supra note 76, at 51-63 (Montgomery bus boycott required mobilized support of local residents).

106. See, e.g., id. at 194-97 (sit-ins could not have been sustained without support of local movement centers created with indigenous participation and financing); H. RAINES, supra note 84, at 117-21 (freedom riders sheltered by elderly black couple).

107. S. BEI.FRAGE, supra note 104.

108. Citizens' Petition for the Redress of Grievances: Hearing Before the Subcomm. on Constitutional Rights of the Senate Comm. on the Judiciary, 84th Cong., 1st Sess. 30 (1955) (statement of Roy Wilkins, Executive Secretary, NAACP) (Southern blacks who signed school desegregation petitions were fired or evicted, and many had business franchises revoked or supply contracts terminated); see also R. KLUGER, supra note 94, 3-26 (detailing harassment of blacks who signed petitions and stood as plaintiffs in school desegregation cases).

109. D. LouIs, supra note 75 , at 14-15.

110. Simon, supra note 6, at 474-84; $f$. MOdel Rules of Professional Conduct Rules 1.2, 
bility of this model to such areas as public defender work, legal assistance programs, and class action litigation. ${ }^{111}$ In these practices, the lawyer may be shaping or limiting the client's goals or interests, possibly to the extent that the relationship is one of domination and manipulation. The empowerment approach is vulnerable to the same problem unless lawyers pay careful attention to achieving a relationship of "genuine equality and mutual respect"112 as Gabel and Harris advocate. The model of a lawyer seeking to create a non-hierarchical community of interest in the course of representation is the ideal. ${ }^{113}$ The lawyer and client should jointly define the client's problem, determine the desired relief, and choose the best course of action. They need to work together to pursue shared goals, each making suggestions about what should be done and each open to persuasion by the other. ${ }^{114}$ If the client has strong political commitments that sharply conflict with those of the lawyer, this kind of relationship cannot develop.

A non-hierarchical relationship, in which lawyer and client share common interests and goals transfers the client from a relationship of coercion to one of empowerment. One successful example of this process is Stephen Wexler's story of the interaction between himself and a group of black women who were trying to get emergency funds for a mother and medical care for her malnourished child. ${ }^{118}$ Following a course of action they suggested, he accompanied them to the welfare office and the hospital even though his initial approach to the problem was different from theirs. His presence contributed to the effort but the women could call the victory theirs because of their role in initiating it and carrying it out.

When client participation is a goal, it is necessary to develop different criteria for determining the best allocation of tasks between attorney and client. On the one hand, the lawyer must try to involve clients in any capacity which contributes to the effort, as well as foster further participation when their experience increases. For example, a client may be able to

1.4 (1981) (lawyer must respect client's decisions about conduct of case); MOdel. Code of ProfesSIONAL. RESPONSIBILITY EC 5-1, 7-7 (1981).

111. See Alschuler, The Defense Attorney's Role in Plea Bargaining, 84 Yale L.J. 1179 (1975); Bell, Serving Two Masters: Integration Ideals and Client Interests in School Desegregation Litigation, 85 Yale L.J. 470 (1976); Bellow, supra note 62; Rhode, Class Conflicts in Class Actions, 34 Stan. L. Rev. 1183 (1982); Simon, The Ideology of Advocacy: Procedural Justice and Professional Ethics, 1978 Wis. L. Rev. 29; Yeazell, From Group Litigation to Class Action-Part II: Interest, Class, and Representation, 27 UCLA L. REv. 1067, 1108-21 (1980).

112. Gabel \& Harris, supra note 6 , at $376,408-10$.

113. Simon, supra note 6 , at $485-86$.

114. Two common objections to this view are that clients have unrealistic expectations about what they can achieve through the legal system and that they want lawyers to handle problems without having to be involved in the process themselves. See Gabel \& Harris, supra note 6, at 409. If true, these are problems that a radical lawyer will have to overcome.

115. See Wexler, Practicing Law for Poor People, 79 YALE L.J. 1049, 1064-65 (1970). 
handle most of his eviction case. He may require assistance from the lawyer in preparing any complex pleadings, or need advice to ensure that he does not make unfavorable concessions, but otherwise may be able to contact building inspectors, file pleadings, attend hearings, and present his own case to the judge. ${ }^{116}$ Clients will gain a sense of personal involvement in the decisions that affect their lives only if they contribute time, energy, ideas, and purpose to the petitioning process.

On the other hand, to say that a client must handle his case is counterproductive when the client cannot reasonably be expected to have the time or resources necessary to pursue the matter. A lawyer should not have a rigid formula to determine how much and what type of client autonomy to encourage. In one case, a lawyer may organize a meeting as a facilitating task; in another, a client will organize the meeting as part of his involvement in and control over the activity. The underlying requirements are that the lawyer and client work cooperatively and that they strive to achieve personal and political empowerment.

\section{G. Collective Action}

Although related to the need for local or individual involvement, the significance of collective action in petitioning warrants separate discussion. Petitioning activity during the Civil Rights Movement was collective at the local and national levels. ${ }^{117}$ The activity was empowering in part because people worked together. ${ }^{118}$ Just as the sit-in movement gained strength from conferences drawing students together from different parts of the country, ${ }^{119}$ a local class action suit can gain strength from the support activites of a national organization. ${ }^{120}$ Lawyers pursuing an empowerment approach must not only encourage clients to work together, but also work together themselves.

Of these two imperatives, cooperation among clients is perhaps the most difficult to achieve in a legal practice. Except when serving as house coun-

116. Some legal aid programs do shift work in this manner, but with different intent-namely, to decrease the lawyer's workload. See Bellow, supra note 62 (workload problems affect client service, including causing low client autonomy). When empowerment is the goal, it may not mean less attorney time but rather time devoted to different pursuits.

117. Although SNCC functioned primarily at the local level, see C. CARSON, supra note 79, at 50 (SNCC's policies determined by field staff, not central office), organizations like the Southern Christian Leadership Conference, Congress of Racial Equality, and the NAACP Legal Defense and Education Fund played key roles at a national level. See, e.g., H. StTkoff, The Strugct.e for Bl,Ack EQUALITY 1954-1980, at 108 (1981) (national and local groups coordinated freedom rides and March on Washington).

118. See, e.g., D. Lours, supra note 75, at 289 (major factor in Civil Rights Movement experience was that there were many people with similar goals).

119. SNCC held annual conferences that were significant in the course of its development as an organization. C. CARson, supra note 79, at 19-25, 66-70, 140-50.

120. See Abel, Lawyers and the Power to Change, supra note 48, at 14. 
sel to community organizations, ${ }^{121}$ lawyers generally face clients who have individualistic approaches to identifying and solving problems and who may not view their problems in a wider political context where the efficacy of group action becomes more apparent. Moreover, organization takes time, effort and resources that poor people who are struggling to get by may not have. ${ }^{122}$ Recognizing these difficulties, lawyers must still encourage collective effort whenever possible. Class action suits can be used to foster collaboration, especially if clients know one another and can take an active role in directing their case. A recent development in class action doctrine that gives class members a direct role in monitoring the decree is a step in this direction. ${ }^{128}$

A lawyer can also stimulate collective action by demonstrating that there are collective solutions to what clients may perceive as individual problems. Indeed, some individual problems can only be solved collectively. For example, when an unarmed man, Reggie Jordan, was killed by police, his relatives were unable to raise the $\$ 180,000$ that they were advised was necessary to bring the case to court. ${ }^{124}$ Poet and writer June Jordan commented: "Unless the execution of Reggie Jordan became a major community cause for organizing, and protest, his murder would simply become a statistical item."125 In this case, the necessary community involvement did not occur. A lawyer in a similar situation should try to mobilize community action and support to help fund a lawsuit, or to publicize and protest the police conduct at fault. This does not mean that a lawyer should be first and foremost a community organizer. The empowerment approach differs from Stephen Wexler's model of the lawyer as

121. Cf. Houseman, supra note 67 (exploring relationships between legal services programs and community groups). For examples of law firms that do this, see B. GARTH, supra note 50, at 179-93; Bachmann, supra note 3; Harris, supra note 56, at 24-25.

122. Lawyers in the late sixties who attempted community organizing had these problems. A study of activist lawyers during that period reported: "Organizing can be very difficult and very discouraging, especially where people are exhausted by their efforts to eke out an existence, and where they are used to struggling for survival against each other rather than working in groups to raise general standards." Comment, The New Public Interest Lawyers, 79 Yale L.J. 1069, 1090 (1970).

123. Morgan v. Kerrigan, 530 F.2d 401, 429 (1st Cir.) (upholding court order for desegregation of Boston public schools, that approved citizen group to monitor desegregation and to attempt to improve quality of education), cert. denied, 426 U.S. 935 (1976), vacated and remanded in part sub nom. Morgan v. McKeigue, 726 F.2d 33 (1st Cir. 1984) (court can only order citizen councils to be involved in desegregation, not educational policy and quality of schools).

124. J. Jordan, Notody Mean More to Me Than You and the Future Life of Willie Jordan, in ON Call: Political Essays 137 (1985). It is unclear why such a large sum was needed to pursue the case. The cost issue raises the difficult question of how radical lawyers following an empowerment approach to legal practice are paid. In the past, leftist lawyers have developed a number of methods, such as foundation grants, community organization funds or taking a percentage of traditional feegenerating cases, to fund their work. See M. JAMES, supra note 46; Bachmann, supra note 57; Lefcourt, The First Law Commune, in LAw Against the PeOple, supra note 49, at 310-26.

125. J. Jordan, supra note 124 , at 134 . 
community organizer because it has different priorities. ${ }^{126}$ The goal of the practice is not to build an organization, but rather to empower people. Although an organization may be helpful and sometimes instrumental in ensuring that petitioning results in empowerment, in some circumstances the two goals may diverge, such as when people needing legal assistance are wary of joining organizations.

\section{Range of Options}

The petitioning model makes a final contribution to empowerment theory by emphasizing that redress of grievances is often obtainable through a variety of methods. While no lawyer focuses on filing a court case as the universal panacea, the lawyer's overall theory of practice will determine what solutions she suggests for her client. ${ }^{127}$ Viewing a lawyer's role as facilitating a petition for redress of grievances emphasizes her responsibility to suggest and assist with a range of legal and non-legal efforts. ${ }^{128} \mathrm{~A}$ client's problem may best be addressed with a demonstration, a hunger strike, a boycott or a traditional petition. For example, in a case where a group of vulnerable single women suffered sexual harassment by a prominent landlord in a rural area, the women wanted to publicize the problem as one way of alleviating it. ${ }^{129}$ One client had the idea of visiting local shelters for abused women who may be looking for accommodation in order to educate them about the problem of sexual harassment by landlords. The lawyer in the case accompanied the client to a shelter in carrying out this essentially community education task. Another idea was that a picket of the landlord's business was an appropriate means of redress because if people in the community were aware that this landlord was illegally conditioning the rental of apartments on women granting sexual favors, he would be less likely or able to continue harassing prospective tenants. In this situation, the lawyer should help her clients evaluate picketing as a

126. See Wexler, supra note 115.

127. See Finman, supra note 46 (legal assistance program activities depended on history and ideology of program).

128. This is not to suggest that alternative dispute resolution is a good option for poor and oppressed groups who have little access to the legal system. Apart from creating a dual system of justice, one for those who can afford lawyers and court fees and another for everyone else, which would exacerbate inequalities, there is also evidence that these mechanisms only work where there is a threat of recourse to the normal court system. See C. Harrington, Shadow Justice 171-72 (1985) (neighborhood justice centers depend on courts for their place and meaning in legal process and, for those who use them, represent loss of forum for political action); No AcCEss To LAw 49, 101 (L. Nader ed. 1984) (only with possibility of using force of law do alternative complaint-handlers work; solution to consumer claims problems should not be two-tiered system).

129. This example is drawn from my experience working with Valley Legal Services, Derby, Connecticut. The case generally was discussed in Complaints Grow as More Tenants Tell of Sexual Harassment by Landlords, N.Y. Times, July 13, 1986, at 27, col. 1. 
course of action, including giving them advice on local permit requirements or the potential of a retaliatory libel suit. ${ }^{130}$

Finally, a range of options is important because petitioning is empowering when it involves activities that are more easily available to otherwise excluded groups. ${ }^{131}$ People attempting to have an effective role in political decisions may have the resources to organize and participate in a mass demonstration protesting welfare cuts yet be unable to wage a media campaign or hire lobbyists. Thus, the petitioning model suggests that the lawyer should encourage clients to consider various forms of political activity.

\section{Conclusion}

Radical lawyers representing poor and oppressed groups in society are in a strategic position. When these clients have a problem leading them to consult a lawyer, the opportunity exists for the lawyer to make the experience an empowering one. Social workers, community organizers, and the clergy may all come in contact with the same groups of people, but lawyers have a unique role as mediators between clients and the legal system. Petitioning has historically been a means of political participation for disenfranchised groups. It can serve as a model illustrating how a lawyer's work can encourage empowerment.

130. In this case the lawyer advised against a picket because the libel implications were too great. Telephone interview with Charisse Hutton, Valley Legal Services (Oct. 24, 1986).

131. See Adderley v. Florida, 385 U.S. 39, 50-51 (1966) (Douglas, J., dissenting); see also H. ZINN, supra note 98, at 218 ("When people turn in desperation to marches and parades, picketing, sit-ins, mass meetings, and Freedom Rides, this suggests that the normal channels of government are inadequate for the expression of their grievances ....."). 